\title{
Impact of Halo and Hormonal Priming on Early Vegetative Growth Phase of Rice Var. MTU 7029
}

\author{
Sananda Mondal ${ }^{1 *}$, Mahesh Kumar ${ }^{2}$ and Bandana Bose ${ }^{2}$ \\ ${ }^{1}$ Dept. of Genetics \& Plant Breeding \& Crop Physiology, Institute of Agriculture, Visva-Bharati, Sriniketan, W.B. (731 236), India \\ ${ }^{2}$ Dept. of Plant Physiology, Institute of Agricultural Sciences, BHU, Varanasi, Uttar Pradesh (221 005), India
}

\section{Corresponding Author}

Sananda Mondal

e-mail: mondalsananda@gmail.com

\author{
Article History \\ Article ID: AR1849k \\ Received in $24^{\text {th }}$ October, 2017 \\ Received in revised form $16^{\text {th }}$ December, 2017 \\ Accepted in final form $29^{\text {th }}$ January, 2018
}

\begin{abstract}
The present piece of work was conducted in the Seed Physiology Laboratory of Institute of Agricultural Sciences, Banaras Hindu University in the year 2011-12, where the rice seeds variety MTU 7029 were primed with different combinations of kinetin (in ppm) and magnesium nitrate (in mM) (2.5 ppm+2 mM, 2.5 ppm+4 mM, 2.5 ppm+6 mM, 2.5 ppm+8 mM, 5 ppm+2 mM, 5 ppm+4 mM, 5 ppm+6 mM, 5 ppm+8 $\mathrm{mM}$ kinetin and magnesium nitrate respectively) whereas; seeds without any treatment referred as control (non-primed). Various physiomorphological (shoot and root lengths (in $\mathrm{cm}$ ), root number, fresh and dry weights (in g)) and biochemical (proline content (mg $\mathrm{g}^{-1} \mathrm{dry} \mathrm{weight}^{-}$ of seedlings), total chlorophyll content $\left(\mathrm{mg} \mathrm{g}^{-1}\right.$ ) and superoxide dismutase activity (unit $\times 10^{2} \mathrm{~g}^{-1} \mathrm{~min}^{-1}$ fresh weight of leaf; at 20 days after sowing)) parameters were studied in the seedlings, obtained from 10, 15 and 20 DAS old primed and non-primed plants. All the primed seeds were found to perform better as compared to non primed control one. However, treatment 2.5 ppm kinetin +4 mM magnesium nitrate performed best among all the treatments and all the studied parameters such as shoot and root lengths, root number, fresh and dry weights, proline content, total chlorophyll content and superoxide dismutase activity in 10, 15 and 20 days after sowing.
\end{abstract}

Keywords: Rice, halo-priming, hormonal priming, magnesium nitrate, kinetin

\section{Introduction}

Priming' is a well-established treatment for enhancing seed quality. Priming treatments are used to synchronize the germination of individual seeds. Since certain germinationrelated processes are initiated, priming generally causes faster germination and emergence, especially under adverse conditions (Paparella et al., 2015). Depending on plant species, seed morphology and physiology, different priming treatments can be applied, all of them triggering the so-called 'pre-germinative metabolism'. This physiological process takes place during early seed imbibition and includes the seed repair response (activation of DNA repair pathways and antioxidant mechanisms), essential to preserve genome integrity, ensuring proper germination and seedling development (Wojtyla et al., 2016; Chen and Arora, 2013; Sharma and Maheshwari, 2015; Kubala et al., 2015a).

Rice (Oryza sativa L.) is the prominent and staple cereal foodstuff for more than half of the world's population, especially in tropical Latin America and East, South and Southeast Asia. Direct seeding of rice in aerobic cultures has emerged as resource conservation technology that saves water, labor, and fuel spent on puddling in transplanted rice cultures (Liu et al., 2014). However, poor germination has been one of the obstacles in its adoption under field conditions (Liu et al., 2014). Various seed priming techniques including hydropriming, osmopriming, hormonal priming, nutrient priming and chemical priming are employed in rice (Farooq et al., 2009; Mondal et al., 2016, Mondal et al., 2011). The aim of the present experiment was to study the potentiality of the nutrient $\left(\mathrm{Mg}\left(\mathrm{NO}_{3}\right)_{2}\right)$ and hormonal priming (Kinetin) during the early growth phase of rice variety MTU 7029.

\section{Materials and Methods}

In the present investigation, before sowing the healthy and bold rice (Oryza sativa L. var. MTU 7029) seeds were surface sterilized by keeping them in $0.1 \% \mathrm{HgCl}_{2}$ (Mercuric chloride) solution for 2 minutes and then thoroughly washed with distilled water for 5-6 times. For priming, the sterilized seeds were soaked in different combinations of $\mathrm{Mg}\left(\mathrm{NO}_{3}\right)_{2}$ (ranging from 2.0 to $8.0 \mathrm{mM}$ ) and kinetin (ranging from 2.5 to $5.0 \mathrm{ppm}$ ) for $20 \mathrm{~h}$ (total 9 treatments $\mathrm{T}_{1}-\mathrm{T}_{9}$ ). After that the seeds were taken out and gently washed with distilled water once and then dried back to its initial weight at the room temperature by placing them under fan. Dried seeds were then packed in paper bags separately for each treatment and were used 
as per requirement but within one month of priming. The seeds without any treatment referred as control (non-primed) and both the primed and non-primed seeds were sown in small pots (3.5×5 inch) in kharif season 2011 in a complete randomized design (CRD) with three replications according to recommended practices. The physio-morphological (shoot and root lengths, root number, fresh and dry weights) and biochemical (proline content, total chlorophyll content and superoxide dismutase activity (SOD at 20 days after sowing)) observations were measured at 10, 15 and 20 days after sowing (DAS). The length of the shoot was taken by using centimetre- scale by placing it on the surface of the soil of the pot and upto the top of the plant leaf. To get the length and number of roots upto 20 days, the seedlings were first watered vigorously and then uprooted very gently to avoid any type of injury to root system of the seedlings. These were kept in a beaker of $1 \mathrm{~L}$ capacity filled with distilled water. The soil present on root surface was washed thoroughly for its proper cleaning. The centimetre scale was placed at the base of shoot to the tip of the longest root to measure the root length. The number of roots of plants was also counted by placing the root part on a glass plate and by using a needle. The dry weight of seedlings was obtained by keeping the sample for an hour in an oven pre-set at $100-110{ }^{\circ} \mathrm{C}$. Thereafter it was placed in another oven, which was set at 60 to $70{ }^{\circ} \mathrm{C}$ till to get the constant weight ( 5 seedlings were taken into consideration for each treatment and per replication). Proline and total chlorophyll content of leaves and SOD activity were measured by using the method of Bates et al (1973), Witham et al. (1971) and Dhindsa et al. (1981) respectively. However, the treatment details were as follows: (i) Control seeds (Non-primed) $\left(T_{1}\right)$, (ii) 2.5 ppm kinetin+2 $\mathrm{mM} \mathrm{Mg}\left(\mathrm{NO}_{3}\right)_{2}\left(\mathrm{~T}_{2}\right)$, (iii) $2.5 \mathrm{ppm}$ kinetin+4 $\mathrm{mM} \mathrm{Mg}\left(\mathrm{NO}_{3}\right)_{2}\left(\mathrm{~T}_{3}\right)$, (iv) $2.5 \mathrm{ppm}$ kinetin+6 mM Mg$\left(\mathrm{NO}_{3}\right)_{2}\left(\mathrm{~T}_{4}\right)$, (v) $2.5 \mathrm{ppm}$ kinetin+8 $\mathrm{mM} \mathrm{Mg}\left(\mathrm{NO}_{3}\right)_{2}\left(\mathrm{~T}_{5}\right)$, (vi) 5 ppm kinetin+2 $\mathrm{mM} \mathrm{Mg}\left(\mathrm{NO}_{3}\right)_{2}\left(\mathrm{~T}_{6}\right)$, (vii) $5 \mathrm{ppm}$ kinetin+4 $\mathrm{mM} \mathrm{Mg}\left(\mathrm{NO}_{3}\right)_{2}\left(\mathrm{~T}_{7}\right)$, (viii) 5 ppm kinetin+6 mM Mg(NO $\left.)_{2}\right)_{8}\left(\mathrm{~T}_{8}\right)$, (ix) 5 ppm kinetin+8 $\mathrm{mM} \mathrm{Mg}\left(\mathrm{NO}_{3}\right)_{2}\left(\mathrm{~T}_{9}\right)$.

\section{Results and Discussion}

In the present experiment, the seeds of rice variety MTU 7029 were primed with different combinations of kinetin and magnesium nitrate. While studying the shoot length of the seedlings at 10, 15 and 20 DAS it was observed that treatment number $\mathrm{T}_{3}(19.6,20.62$ and $24.95 \mathrm{~cm})$ and $\mathrm{T}_{7}(18.13,20.74$ and $23.72 \mathrm{~cm}$ ) were showed best result at all the three days and statistically significant at 1 and $5 \%$ level of significance followed by the other treatments. However in case of root length the treatment $T_{3}(9.87,14.53$ and $18.04 \mathrm{~cm})$ has shown the best result as compared to the other treatments and statistically significant at 1 and $5 \%$ level of significance at all the three studied DAS. Whereas the treatment $T_{3}(6,8.7$ and 14 respectively) showed the highest number of roots at all the studied three days was recorded (Table 1). When we taken the observation of fresh weight in all the 3 DAS the treatment $\mathrm{T}_{6}$ represented $5 \mathrm{ppm}$ kinetin+2 $\mathrm{mM} \mathrm{Mg}\left(\mathrm{NO}_{3}\right)_{2}$ $(0.37,0.48$ and 0.69 g respectively) showed maximum value and statistically significant as compared to other treatments. Again in combined primed seedlings were kept in oven for taking the reading of dry weight then it was observed that the treatment number $T_{5}$ to $T_{8}(0.1 \mathrm{~g}), T_{3}$ to $T_{4}$ and $T_{6}$ to $T_{7}(0.11$ g) and $T_{2}$ to $T_{9}(0.11 \mathrm{~g})$ showed highest value at 10,15 and 20 DAS respectively (Table 2 ). The data regarding the combined treatment $\mathrm{T}_{5}(0.96,1.00$ and 1.04 respectively) showed best

Table 1: Effect of kinetin and magnesium nitrate priming in combination on shoot and root lengths, root no. of rice variety MTU 7029

\begin{tabular}{|c|c|c|c|}
\hline \multirow[t]{2}{*}{ Treatments } & \multicolumn{3}{|c|}{ Shoot length $(\mathrm{cm})$} \\
\hline & 10 DAS & 15 DAS & 20 DAS \\
\hline Control $\left(\mathrm{T}_{1}\right)$ & 13.22 & 15.66 & 17.13 \\
\hline $2.5 \mathrm{ppm}+2 \mathrm{mM}\left(\mathrm{T}_{2}\right)$ & 17.05 & 20.00 & 22.74 \\
\hline $2.5 \mathrm{ppm}+4 \mathrm{mM}\left(\mathrm{T}_{3}\right)$ & 19.60 & 20.62 & 24.95 \\
\hline $2.5 \mathrm{ppm}+6 \mathrm{mM}\left(\mathrm{T}_{4}\right)$ & 11.78 & 14.17 & 17.71 \\
\hline $2.5 \mathrm{ppm}+8 \mathrm{mM}\left(\mathrm{T}_{5}\right)$ & 12.08 & 14.55 & 18.06 \\
\hline $5 \mathrm{ppm}+2 \mathrm{mM}\left(\mathrm{T}_{6}\right)$ & 13.40 & 15.46 & 18.44 \\
\hline $5 \mathrm{ppm}+4 \mathrm{mM}\left(\mathrm{T}_{7}\right)$ & 18.13 & 20.74 & 23.72 \\
\hline $5 \mathrm{ppm}+6 \mathrm{mM}\left(\mathrm{T}_{8}\right)$ & 14.77 & 17.53 & 20.19 \\
\hline $5 \mathrm{ppm}+8 \mathrm{mM}\left(\mathrm{T}_{9}\right)$ & 15.12 & 17.98 & 21.00 \\
\hline SEm \pm & 0.41 & 0.39 & 0.48 \\
\hline $\mathrm{CD}(p=0.05)$ & 0.69 & 0.67 & 0.83 \\
\hline \multirow[t]{2}{*}{$\operatorname{CD}(p=0.01)$} & 1.02 & 0.97 & 1.20 \\
\hline & \multicolumn{3}{|c|}{ Root length $(\mathrm{cm})$} \\
\hline Control $\left(T_{1}\right)$ & 4.16 & 8.75 & 12.75 \\
\hline $2.5 \mathrm{ppm}+2 \mathrm{mM}\left(\mathrm{T}_{2}\right)$ & 6.97 & 11.37 & 16.1 \\
\hline $2.5 \mathrm{ppm}+4 \mathrm{mM}\left(\mathrm{T}_{3}\right)$ & 9.87 & 14.53 & 18.04 \\
\hline $2.5 \mathrm{ppm}+6 \mathrm{mM}\left(\mathrm{T}_{4}\right)$ & 6.13 & 10.78 & 13.92 \\
\hline $2.5 \mathrm{ppm}+8 \mathrm{mM}\left(\mathrm{T}_{5}\right)$ & 5.40 & 9.01 & 13.89 \\
\hline $5 \mathrm{ppm}+2 \mathrm{mM}\left(\mathrm{T}_{6}\right)$ & 4.75 & 9.22 & 14.0 \\
\hline $5 \mathrm{ppm}+4 \mathrm{mM}\left(\mathrm{T}_{7}\right)$ & 6.38 & 12.49 & 15.79 \\
\hline $5 \mathrm{ppm}+6 \mathrm{mM}\left(\mathrm{T}_{8}\right)$ & 6.77 & 12.88 & 15.6 \\
\hline $5 \mathrm{ppm}+8 \mathrm{mM}\left(\mathrm{T}_{9}\right)$ & 5.71 & 12.5 & 15.2 \\
\hline SEm \pm & 0.21 & 0.42 & 0.58 \\
\hline $\operatorname{CD}(p=0.05)$ & 0.37 & 0.72 & 0.97 \\
\hline \multirow[t]{2}{*}{$\operatorname{CD}(p=0.01)$} & 0.52 & 1.05 & 1.45 \\
\hline & \multicolumn{3}{|c|}{ Root number } \\
\hline Control $\left(T_{1}\right)$ & 2.8 & 3.1 & 4.20 \\
\hline $2.5 \mathrm{ppm}+2 \mathrm{mM}\left(\mathrm{T}_{2}\right)$ & 5.3 & 8.2 & 12.3 \\
\hline $2.5 \mathrm{ppm}+4 \mathrm{mM}\left(\mathrm{T}_{3}\right)$ & 6.0 & 8.7 & 14.0 \\
\hline $2.5 \mathrm{ppm}+6 \mathrm{mM}\left(\mathrm{T}_{4}\right)$ & 4.3 & 7.8 & 11.0 \\
\hline
\end{tabular}




\begin{tabular}{lccc}
\hline Treatments & \multicolumn{3}{c}{ Root number } \\
\cline { 2 - 4 } & 10 DAS & 15 DAS & 20 DAS \\
\hline $2.5 \mathrm{ppm}+8 \mathrm{mM}\left(\mathrm{T}_{5}\right)$ & 4.3 & 7.0 & 12.0 \\
$5 \mathrm{ppm}+2 \mathrm{mM}\left(\mathrm{T}_{6}\right)$ & 4.5 & 7.0 & 11.0 \\
$5 \mathrm{ppm}+4 \mathrm{mM}\left(\mathrm{T}_{7}\right)$ & 4.5 & 6.0 & 10.0 \\
$5 \mathrm{ppm}+6 \mathrm{mM}\left(\mathrm{T}_{8}\right)$ & 4.3 & 5.0 & 9.00 \\
$5 \mathrm{ppm}+8 \mathrm{mM}\left(\mathrm{T}_{9}\right)$ & 4.7 & 6.0 & 11.00 \\
$\mathrm{SEm} \pm$ & 0.0026 & 0.0074 & 0.0049 \\
$\mathrm{CD}(p=0.05)$ & 0.0046 & 0.0124 & 0.0084 \\
$\mathrm{CD}(p=0.01)$ & 0.0065 & 0.0185 & 0.0122 \\
\hline
\end{tabular}

result in all the 3 study period when proline content ( $\mathrm{mg} \mathrm{g}^{-1} \mathrm{dry}$ weight of seedlings) was estimated. Whereas, the treatment

Table 2: Effect of kinetin and magnesium nitrate priming in combination on fresh and dry weights of rice variety MTU 7029

\begin{tabular}{|c|c|c|c|}
\hline \multirow[t]{2}{*}{ Treatments } & \multicolumn{3}{|c|}{ Fresh weight (g) } \\
\hline & 10 DAS & 15 DAS & 20 DAS \\
\hline Control $\left(\mathrm{T}_{1}\right)$ & 0.21 & 0.24 & 0.37 \\
\hline $2.5 \mathrm{ppm}+2 \mathrm{mM}\left(\mathrm{T}_{2}\right)$ & 0.31 & 0.39 & 0.62 \\
\hline $2.5 \mathrm{ppm}+4 \mathrm{mM}\left(\mathrm{T}_{3}\right)$ & 0.34 & 0.45 & 0.68 \\
\hline $2.5 \mathrm{ppm}+6 \mathrm{mM}\left(\mathrm{T}_{4}\right)$ & 0.33 & 0.44 & 0.67 \\
\hline $2.5 \mathrm{ppm}+8 \mathrm{mM}\left(\mathrm{T}_{5}\right)$ & 0.33 & 0.47 & 0.68 \\
\hline $5 \mathrm{ppm}+2 \mathrm{mM}\left(\mathrm{T}_{6}\right)$ & 0.37 & 0.48 & 0.69 \\
\hline $5 \mathrm{ppm}+4 \mathrm{mM}\left(\mathrm{T}_{7}\right)$ & 0.37 & 0.44 & 0.65 \\
\hline $5 \mathrm{ppm}+6 \mathrm{mM}\left(\mathrm{T}_{8}\right)$ & 0.36 & 0.44 & 0.65 \\
\hline $5 \mathrm{ppm}+8 \mathrm{mM}\left(\mathrm{T}_{9}\right)$ & 0.35 & 0.43 & 0.63 \\
\hline SEm \pm & 0.003 & 0.003 & 0.003 \\
\hline $\mathrm{CD}(p=0.05)$ & 0.005 & 0.006 & 0.005 \\
\hline \multirow[t]{2}{*}{$C D(p=0.01)$} & 0.008 & 0.009 & 0.007 \\
\hline & \multicolumn{3}{|c|}{ Dry weight (g) } \\
\hline Control $\left(\mathrm{T}_{1}\right)$ & 70.00 & 90.00 & 100.00 \\
\hline $2.5 \mathrm{ppm}+2 \mathrm{mM}\left(\mathrm{T}_{2}\right)$ & 90.00 & 100.00 & 110.00 \\
\hline $2.5 \mathrm{ppm}+4 \mathrm{mM}\left(\mathrm{T}_{3}\right)$ & 90.00 & 110.00 & 110.00 \\
\hline $2.5 \mathrm{ppm}+6 \mathrm{mM}\left(\mathrm{T}_{4}\right)$ & 90.00 & 110.00 & 110.00 \\
\hline $2.5 \mathrm{ppm}+8 \mathrm{mM}\left(\mathrm{T}_{5}\right)$ & 100.00 & 100.00 & 110.00 \\
\hline $5 \mathrm{ppm}+2 \mathrm{mM}\left(\mathrm{T}_{6}\right)$ & 100.00 & 110.00 & 110.00 \\
\hline $5 \mathrm{ppm}+4 \mathrm{mM}\left(\mathrm{T}_{7}\right)$ & 100.00 & 110.00 & 110.00 \\
\hline $5 \mathrm{ppm}+6 \mathrm{mM}\left(\mathrm{T}_{8}\right)$ & 100.00 & 100.00 & 110.00 \\
\hline $5 \mathrm{ppm}+8 \mathrm{mM}\left(\mathrm{T}_{9}\right)$ & 90.00 & 100.00 & 110.00 \\
\hline SEm \pm & 0.001 & 0.001 & 0.0009 \\
\hline $\mathrm{CD}(p=0.05)$ & 0.002 & 0.002 & 0.0016 \\
\hline $\mathrm{CD}(p=0.01)$ & 0.003 & 0.004 & 0.0023 \\
\hline
\end{tabular}

$\mathrm{T}_{3}(0.332,0.468$ and 0.499$)$ showed best result as compared to the other treatments at all the three days in case of total chlorophyll content. Superoxide dismutase activity of rice seedling was studied at 20 DAS and the treatment $T_{3}$ (17.1) showed the highest enzyme activity (Figure 1).

Rapid germination and emergence are essential for successful crop establishment, for which seed priming could play an
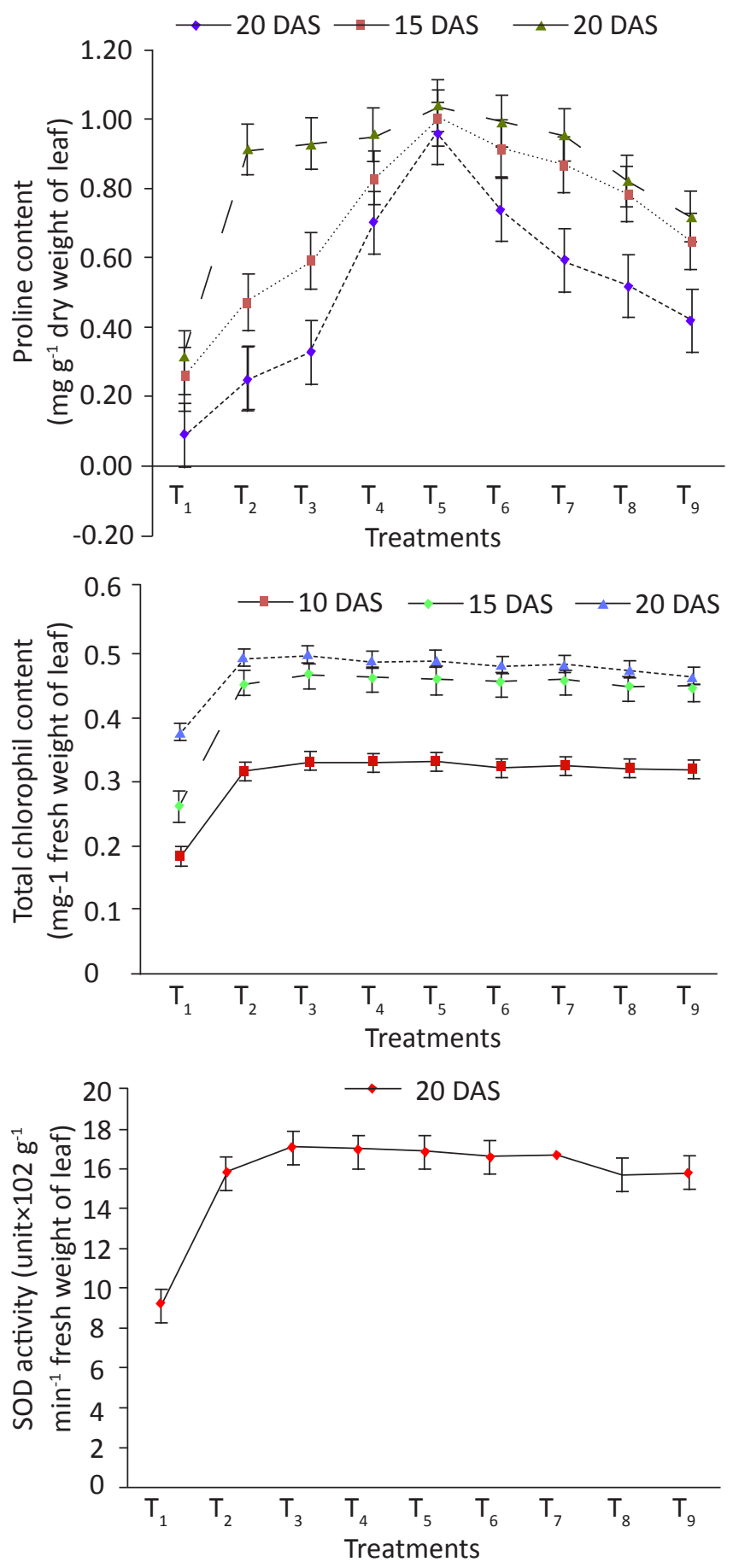

Figure 1. Effect of kinetin and magnesium nitrate priming in combination on proline content, total chlorophyll content and super oxide dismutase activity of rice var. MTU 7029 
important role. Seed priming is an effective technology to enhance rapid and uniform emergence and to achieve high vigour, leading to better stand establishment and yield. It is a simple and low cost hydration technique in which seeds are partially hydrated to a point where pre-germination metabolic activities start without actual germination, and then re-dried until close to the original dry weight. Srivastava and Bose (2012) conducted an experiment on seed priming of rice varieties with or without nitrate salts $\left(\mathrm{Mg}\left(\mathrm{NO}_{3}\right)_{2}\right.$ and $\left.\mathrm{KNO}_{3}\right)$. They concluded that the nitrate priming treatments in rice increases the plant height, leaf area and number of leaf and yield attribute characteristics i.e. fertile tillers, panicle and grain quality with nitrate treated varieties. In the present piece of work the rice seeds were primed with magnesium nitrate and kinetin combinedly and the result shows that there were an increased shoot and root lengths, root number, fresh weight and dry weights, proline content, total chlorophyll content and superoxide dismutase activity in the seedlings of primed seeds as compared to nonprime control one. These results resembles with the previous experiment done by the various scientists. Similarly, in rice, seed priming treatment was known to cause increase in seedling growth parameters (Goswami et al., 2013), and it was also reported that seed priming treatments reduced the time taken to initiate the germination process, improved the rate of germination and synchronization, enhanced the lengths of shoot and root and thus increased the fresh and dry weight of the seedlings (Ruan et al., 2002; Mathew and Mohanasarida, 2005; Farooq et al., 2006).

Root number and root length both are very important criteria for a growing crop. It gives the proper anchorage to the plant side by side it also helps the seedlings to absorb water and minerals from the soil. In addition, Mondal et al. (2016) reported that kinetin upto certain extent improve the number of roots in the rice variety MTU-7029. So kinetin treatment in form of seed priming may produce vigorous seedling due to the formation of more number of root and long length of the same in which latter will help to search the water from the soil in a growing crop and improved the seedling vigour. However, Srivastava (2002) showed a closed correlation between an improved seedling growth characteristics and greater production of roots is essential to an increased level of cell division after the germinative phase of plant growth. In the present case, when both salt and PGR given in combination more roots were noted to form in the rice variety MTU-7029. For instance, kinetin, specifically play a critical role for the accumulation of source properly, for enhancing the performance of sink in particular part (Banerji and Laloraya, 1965; Sugiura, 1963) of organ of the plant/crop and help in cell division which leads to overall growth and development of the plants.

In this experiment magnesium nitrate and kinetin was used for priming purpose in which $\mathrm{Mg}$ is the central atom in the chlorophyll molecule and also act as cofactor for a number of important enzymes of plant system side by side nitrate is also an important component, could be absorbed and being used in the different metabolism, through the enzyme nitrate reductase. It can also act as a signalling element and activate the antioxidant metabolism. Whereas, the stimulation by cytokinins of chlorophyll (Chl) biosynthesis (Sigiura, 1963), Averina, and Shlyk, (1972) is at least partly due to activated synthesis of 5-aminolevulinic acid (ALA), the first specific precursor of all tetrapyrroles (Fletcher, 1973). The increased rate of ALA synthesis results from both the increased level of transcripts for glutamyl-tRNA reductase known to catalyze ALA formation and from the higher activity of this enzyme (Masuda et al., 1995). In the present piece of work, total chlorophyll content of the leaves of the primed seedlings was more as compared to non primed one that is the combined effect of the $\mathrm{Mg}\left(\mathrm{NO}_{3}\right)_{2}$ and kinetin.

In present experiment, when nitrate salt and kinetin, were applied in combined form highest amount of proline content in the leaves of seedlings was observed this is might be due to the combined effect of the two chemical which create some stressful environment inside the plant system and provoke to synthesize more amount of proline inside the cell. The result suggested that the increment in the proline may improve the stress ameliorating capacity in the growing crops being an important molecule for osmo-regulation in plants in adverse condition during growth (Mondal et al., 2016, Jisha and Puthur, 2016).

Among the antioxidant enzymes, SOD constitutes the primary line of defense as it dismutates the superoxide radicals to hydrogen peroxide (Fatima and Ahmad, 2005). BABA priming caused the enhanced activities of POD and SOD in rice seedlings raised from primed seeds as reported by Jisha and Puthur, (2016). There are previous reports on enhanced activities of POD and SOD under the influence of seed priming in rice cultivars (Sun et al., 2010; Goswami et al., 2013). In the present case, the activity of SOD enzyme was more in primed seeds. For this parameter the rice seeds primed with higher concentration of salt or PGR showed higher values. Similar type of results was also observed by Anaytullah et al. (2012) in wheat while primed with the nitrate salts $\left(\mathrm{KNO}_{3}\right.$ and $\left.\mathrm{Mg}\left(\mathrm{NO}_{3}\right)_{2}\right)$.

\section{Conclusion}

There are no reports on the seed priming using $\mathrm{Mg}\left(\mathrm{NO}_{3}\right)_{2}$ and kinetin combinedly. Application of $\mathrm{Mg}\left(\mathrm{NO}_{3}\right)_{2}$ and kinetin combinedly at the seed stage has advantages over the application at the seedling stage. The later type of application requires large quantity of the chemical. Moreover, very less quantity of the chemical may penetrate inside the plant by traversing the cuticle and epidermis. For seed priming in rice variety MTU-7029, a very low concentration of 2.5 ppm kinetin+4 $\mathrm{mM} \mathrm{Mg}\left(\mathrm{NO}_{3}\right)_{2}$ is use-off and a positive result obtained in enhancing the growth and development of the seedlings. 


\section{References}

Anaytullah, Srivastava, A.K., Bose, B., 2012.Impact of seed hardening treatment with nitrate salts on nitrogen and anti oxidant defense metabolisms in Triticum aestivum L. under different sowing conditions. Vegetos 25(1), 292-299.

Averina, N.G., Shlyk, A.A., 1972. Effect of Kinetin on Accumulation and Activity of Protochlorophyllide in Etiolated and Post-Etiolated Barley Leaves, Sov. Plant Physiology 19, 487-496.

Bates, L.S., Waldren, R.P., Teare, I.D., 1973. Rapid determination of free proline for water stress studies. Plant Soil 39, 205-207.

Chen, K., Arora, R., 2013. Priming memory invokes seed stresstolerance. Environmental and Experimental Botany 94, 33-45.

Dhindsa, R.A., Plumb-Dhindsa, P., Thorpe, T.A., 1981. Leaf senescence: correlated with increased permeability and lipid peroxidation, and decreased level of super oxide dismutase and catalase. Journal of Experimental Botany 126, 93-101.

Farooq, M., Basra, S.M.A., Hafeez, K., 2006. Seed invigoration by osmohardening in fine and course rice. Seed Science and Technology 34(1), 181-187.

Farooq, M., Basra, S.M.A, Wahid, A., Khaliq A., Kobayashi, N., 2009b. Rice seed invigoration: a review. In: E. Lich Lichtfouse (Ed.), Organic Farming, Pest Control and Remediation of Soil Pollutants, Springer, the Netherlands, 137-175.

Fatima, R.A., Ahmad, M., 2005. Certain antioxidant enzymes of Allium cepa as biomarkers for the detection of toxic heavy metals in wastewater. Science and Total Environment 346(1-3), 256-73.

Fletcher, R., Teo, S., Alt, A., 1973. Stimulation of Chlorophyll Synthesis in Cucumber Cotyledons by Benzyladenine, Canadian Journal of Botany 51, 937-939.

Goswami, A., Banerjee, R., Raha, S., 2013. Drought resistance in rice seedlings conferred by seed priming: Role of the anti-oxidant defense mechanisms. Protoplasma 250, 1115-1129.

Jisha, K.C., Puthur, J.T., 2016. Seed priming with beta-amino butyric acid improves abiotic stress tolerance in rice seedlings. Rice Science 23(5), 242-254.

Kubala, S., Garnczarska, M., Wojtyla, Ł., Clippe, A., Kosmala, A., Zmienko, A. et al., 2015a. Deciphering priminginduced improvement of rapeseed (Brassica napus L.) germination through an integrated transcriptomic and proteomic approach. Plant Science 231, 94-113.

Liu, H. et al., 2014. Progress and constraints of dry directseeded rice in China. Journal of Food Agricultural
Environment 12, 465-472.

Liu, H. et al., 2014. Dry direct-seeded rice as an alternative to transplanted-flooded rice in Central China. Agronomy for Sustainable Development 10.1007/s13593-0140239-0.

Masuda, T., Ohta, H., Shioi, Y., Tsuji, H., Takamiya, K., 1995. Stimulation of glutamyl-t-RNA reductase activity by benzyladenine in greening cucumber cotyledons. Plant Cell Physiology 36, 1237-1243.

Mathew, J., Mohanasarida, K., 2005. Seed priming on crop establishment and seedling vigour in semi-dry rice (Oryza sativa). Research on Crops 23-25.

Mondal, S., Singh, R.P., Bose, B., 2016. Effect of hydro and hormonal priming on seedling vigour during initial vegetative growth of rice (Oryza sativa L.). International Journal of Agriculture, Environment and Biotechnology 9(6), 1125-1130.

Mondal, S., Vijai, P., Bose, B., 2011. Role of seed hardening in rice variety Swarna (MTU 7029). Research Journal of Seed Science 4(3), 157-165.

Paparella, S., Araujo, S.S., Rossi, G., Wijayasinghe, M., Carbonera, D., Balestrazzi, A., 2015. Seed priming: state of the art and new perspectives. Plant Cell Reports 34, 1281-1293.

Ruan, S., Xue, Q., Tylkowska, R., 2002. Effects of priming on seed germination and health of rice (Oryza sativa L.) seeds. Seed Science and Technology 30, 451-458.

Sharma, S.N., Maheshwari, A., 2015. Expression patterns of DNA repair genes associated with priming small and large chickpea (Cicer arietinum) seeds. Seed Science and Technology 43, 250-261.

Sigiura, M., 1963. Promotion of chlorophyll synthesis by kinetin. Botanical Magazine 76, 309-310.

Srivastava, A.K., Bose, B., 2012. Effect of nitrate seed priming on phenology, growth rate and yield attributes in rice (Oryza sativa L.), Vegetos 25(2), 174-181.

Srivastava, L.M., 2002. Plant growth and development: Hormones and environment. $1^{\text {st }}$ Edn., Academic Press, New York, pp: 772.

Sun, Y.Y., Sun, Y. J., Wang, M. T., Li, X.Y., Guo, X., Hu, R., Ma, J., 2010. Effects of seed priming on germination and seedling growth under water stress in rice. Acta Agronomica Sinica 36, 1931-1940.

Witham, F.M., Devid, F.B., Roberts, M.D., 1971. Experimental Plant Physiology 55-56.

Wojtyla, L., Lechowska, K., Kubala, S., Garnczarska, M., 2016. Molecular processes induced in primed seeds-increasing the potential to stabilize crop yields under drought conditions. Journal of Plant Physiology 203, 116-126. 